\title{
The Action of Poisons upon Chlamydomonas and other vegetable Cells.
}

\author{
BY
}

\author{
H. W. HARVEY. \\ Downing College, Cambridge.
}

\section{The Toxic Action of Various Isomers upon Vegetable Cells.}

$\mathrm{T}^{\mathrm{H}}$

$\mathrm{HE}$ toxic action of dilute solutions of the isomers of various benzene derivatives upon the roots of young lupine plants has been studied by Hunkel and True, ${ }^{1}$ and also the effect of a small number of these isomers upon Spirogyra. The toxic activity in these cases does not depend upon the hydrogen ions, for the dissociation in each case is shown to be too slight to have any very appreciable effect. Hunkel and True determined the minimal concentration of the isomers required to kill practically all the young lupine roots immersed in them within forty-eight hours; these concentrations, expressed in gramme molecular weights per litre, are shown for a few cases in the second column of Table I. From a comparison of these concentrations it is seen that 'the toxic power of the para-derivative is in most cases, but not invariably, much greater than that of the ortho- or meta-derivative'. This conclusion was previously arrived at for bacteria by Carnelli and Frue, ${ }^{2}$ who experimented with gelatine plates containing various concentrations of the isomers, which were exposed to the air of a dusty room in order to inoculate them.

In the third column of Table I the order of toxic strength of the poisons is given; these were obtained, for the cresols by Fränkel and for the phthalic acids by myself, by adding a drop of a culture of the bacteria to a tube of dilute poison, and inoculating tubes of suitable media from this at regular intervals.

I have investigated the effects of these isomers upon Chlamydomonas, and determined the minimal concentrations of the various isomers required to cause cessation of movement in a culture of actively motile Chlamydomonas multifilis in ten minutes. These concentrations are given in the first column of Table I. It was found possible to estimate the concentrations required

1 Hunkel and True : Botanisches Centralblatt, B. 76, pp. 231, 289, 36I.

${ }^{2}$ Carnelli and Frue: Journal Chemical Society, vol. 57, p. 636 .

[Annals of Botany, Vol. XXIII. No. XC. April, 1909.] 
to within 10-I5 per cent., a much greater degree of accuracy than was possible with lupines. In some cases, as with resorcin, the difference in the effects caused by a $\frac{1}{6}$ per cent. and $a_{7}$ per cent. solution was well marked ; in other cases a similar difference in the concentration of the poison caused a much less marked effect.

The Table shows both the very similar reactivity of widely different vegetable cells towards the same poison-a somewhat striking phenomenon-and also a fairly constant relation between the chemical constitution of a poison and its toxic strength, since the para-derivative is in most cases the strongest poison of the three isomers. A close relation between the cessation of the power of movement of the Chlamydomonadine cell and its death-point is indicated.

TABLE I.

\begin{tabular}{|c|c|c|c|}
\hline \multirow{2}{*}{ Poison. } & \multicolumn{3}{|c|}{ Minimal Conct. in Gm. Molecular Wts. per Litre. } \\
\hline & Chlamydomonas. & Lupinus Albus. ${ }^{1}$ & Bacteria. \\
\hline $\left.\begin{array}{l}\text { ortho } \\
\text { meta } \\
\text { para }\end{array}\right\}$ dihydroxy phenol & $\begin{array}{l}0.0091 \\
0.0167 \\
0.000182\end{array}$ & $\begin{array}{l}0.00125 \\
0.005 \\
0.000062\end{array}$ & A powerful disinfectant ${ }^{1}$ \\
\hline $\left.\begin{array}{l}\text { ortho } \\
\text { meta } \\
\text { para }\end{array}\right\}$ Cresol & $\begin{array}{l}0.00316 \\
0.00159\end{array}$ & $\begin{array}{l}0.00125 \\
0.00125 \\
0.00062\end{array}$ & $\begin{array}{l}\mathrm{I}^{2} \\
3 \\
2\end{array}$ \\
\hline $\left.\begin{array}{l}\text { ortho } \\
\text { meta } \\
\text { para }\end{array}\right\}$ Phthalic acid & $\begin{array}{l}0.0018 \\
0.00072 \\
0.000012\end{array}$ & & $\begin{array}{l}1^{3} \\
2 \\
3\end{array}$ \\
\hline
\end{tabular}

\section{The Reaction Velocity of Hydrochloric acid as a Poison.}

A small quantity of a culture of a large and actively-moving species of Chlamydomonas was introduced into a cylindrical glass vessel with a thin glass bottom. The cells swam about rapidly within a short distance from the bottom of the vessel, and were viewed with an inverted microscope in a strong red light from above. After introduction of the poison the cells were seen to fall one by one and rest on the bottom. The number thus brought to rest within the field of the microscope was counted at intervals of five minutes.

If the cessation of movement of the cells in this case was a measure of

1 Hunkel and True : Botanisches Centralblatt, B. 76, pp. 23I, 289, 36r.

${ }^{2}$ C. Fränkel: Zeitsch. für Hygiene, 1889. The numbers give the order of increasing toxic strength.

${ }^{3}$ Order of toxic strength with Bacterium subtilis obtained in the same manner as in Fränkel's experiment. 
the time of their death, the counts gave a measure of the number of deaths which had taken place after the various intervals of time, and consequently of the number surviving after these intervals. That this is the case seems most probable from the results obtained. If $n_{1}=$ number of cells surviving after an interval of time $t_{1}$, and $n_{2}$ the number surviving after $t_{2}$, then the equation

$$
\frac{1}{t_{2}-t_{1}} \log \frac{n_{1}}{n_{2}}=\text { a constant }
$$

is found to be approximately obeyed, within the limits of experimental

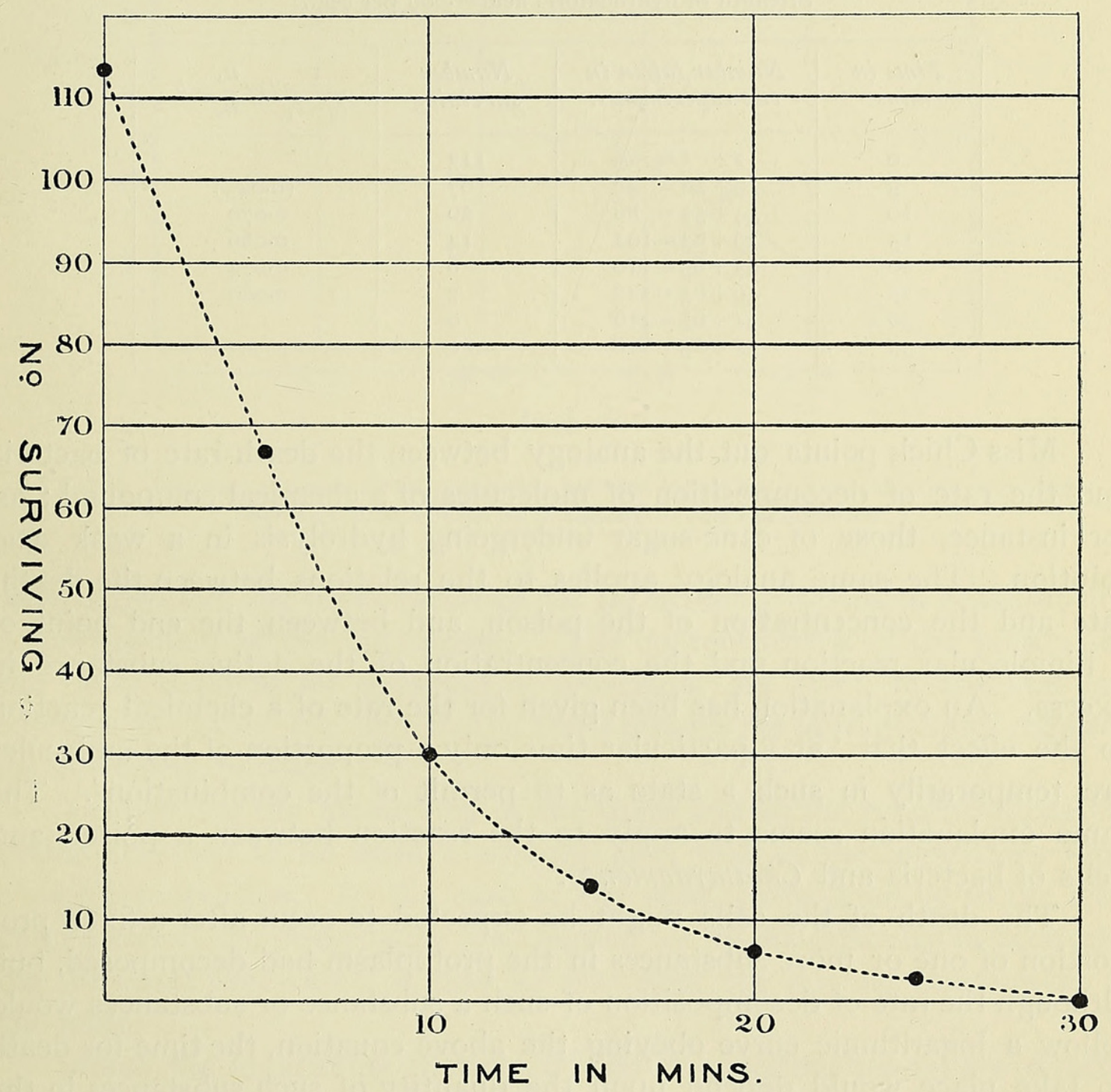

FIG. I. Curve showing relation between number surviving and time (actual).

error, as seen in the fourth column of Table II. Owing to the difficulty of obtaining suitable material, I was unable to repeat the two experiments, the results of which are shown, or to obtain larger and more satisfactory numbers. 
The above equation is the same as that for a unimolecular chemical reaction, if $n_{1}$ is the active mass after time $t_{1}$, and $n_{2}$ is the active mass after time $t_{2}$. A bimolecular chemical reaction in which one active mass is in great excess approximates in velocity to a unimolecular reaction. The same equation as the above was arrived at by Madsen and Nyman, and independently by Miss Chick ${ }^{1}$ in 1907 , for the rate of disinfection of bacteria.

Results of a similar nature have been obtained by Dr. F. F. Blackman ${ }^{2}$ and Miss N. Darwin for the death-rate with higher plants.

TABLE II.

Strength of hydrochloric acid $=.009$ per cent.

\begin{tabular}{|c|c|c|c|}
\hline $\begin{array}{l}\text { Time in } \\
\text { mins. }\end{array}$ & $\begin{array}{l}\text { Number fallen in } \\
\text { two experiments. }\end{array}$ & $\begin{array}{l}\text { Number } \\
\text { surviving }\end{array}$ & $\frac{\mathrm{I}}{t_{2}-t_{1}} \log \frac{n_{1}}{n_{2}}=k$ \\
\hline o & $2+I=3$ & I I 3 & \\
\hline 5 & $19+28=49$ & 67 & $(0.045)$ \\
\hline IO & $34+5^{2}=86$ & 30 & 0.070 \\
\hline I 5 & $39+63=102$ & I4 & 0.066 \\
\hline 20 & $45+65=110$ & 6 & 0.074 \\
\hline 25 & $49+65=113$ & 3 & 0.060 \\
\hline 30 & $5 \mathrm{I}+65=116$ & $\circ$ & \\
\hline 35 & $5 \mathrm{I}+65=\mathrm{II} 6$ & $\circ$ & \\
\hline
\end{tabular}

Miss Chick points out the analogy between the death-rate of bacteria and the rate of decomposition of molecules of a chemical compound; as, for instance, those of cane-sugar undergoing hydrolysis in a weak acid solution. The same analogy applies to the relations between the deathrate and the concentration of the poison, and between the end point of a bimolecular reaction and the concentration of the active substance in excess. An explanation has been given for the rate of a chemical reaction to the effect that 'at a particular time only a proportion of the molecules are temporarily in such a state as to permit of the combination'. The same explanation seems to apply to the reaction between a poison and cells of bacteria and Chlamydomonas.

The death of the cells might be expected to occur after a fixed proportion of one or more substances in the protoplasm had decomposed, but, although the rate of decomposition of such a substance or substances would follow a logarithmic curve obeying the above equation, the time for death to take place would depend upon the quantity of such substances in the individual cells, and upon the proportion necessary to be decomposed before death took place. Why the cells of bacteria and Chlamydomonas behave in this way, like the molecules of a chemical compound, has yet to be explained. 


\section{Variation of the death-rate with the Concentration of the Poison.}

To small quantities of a culture of very numerous actively-moving cells of Chlamydomonas about I cc. of Resorcin solutions of different strengths

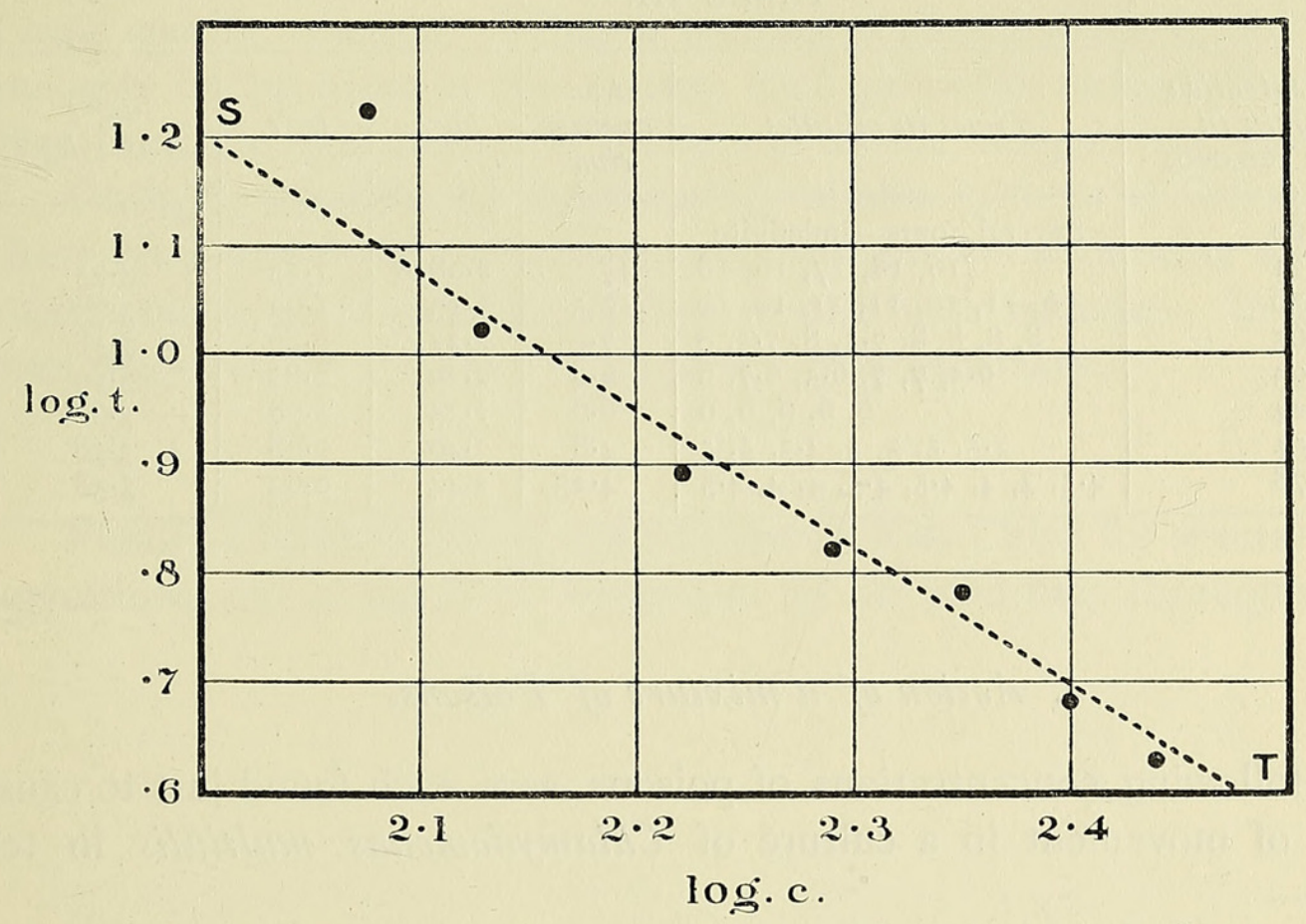

FIG. 2. Diagram showing direct proportion between logarithm of concentration of poison and logarithm of time for poisoning to reach completion.

were added and the times recorded for all, except 3-5 cells, to cease moving under the field of the microscope. The concentrations of the poison and the times required for cessation of movement are given in the first two columns of Table III, and in the third column the average times required for movement to cease.

On plotting the logarithms of the times and of the concentrations the points are seen to lie upon a straight line; that is, the logarithms show a direct proportion. In the case of the point corresponding to the least concentration, the discrepancy is accounted for by the difficulty in determining the exact time-value, as may be seen from the varying values given in the table.

Since the logarithms of time $(t)$ and of concentration $(c)$ are directly proportional

$$
\log t+k \log c=\text { a constant. }
$$

This is found to be the case, taking $k=\mathbf{I} \cdot 2 \mathbf{I}$, as shown by the constant values in the last column.

In a chemical reaction where one molecule of one compound reacts with $k$ molecules of another compound which is in great excess, this equation is 
obeyed when the concentration $(c)$ is made to vary, $t$ being the time for the reaction to reach completion in each case.

In the disinfection of bacteria the same equation is obeyed, the value of $k$ being dependent upon the nature of the poison and the bacterium. ${ }^{1}$

TABLE III.

\begin{tabular}{|c|c|c|c|c|c|}
\hline $\begin{array}{c}C=\text { concentration } \\
\text { of Resorcin in } \\
\text { parts per } 100,000 .\end{array}$ & Times in minutes. & $\begin{array}{l}\text { tor } \\
\text { average } \\
\text { time. }\end{array}$ & $\log c$ & $\log t$ & $\begin{array}{c}\log t \\
+\mathrm{I} \cdot 2 \mathrm{I} \log c .\end{array}$ \\
\hline 102 & Several hours-indefinite & I7 & 2.0828 & $\mathrm{I} \cdot 23$ & 3.75 \\
\hline I 36 & Іо, II, Іо, Іі, Іі, Іо, Іо & 10.5 & $2 \cdot 13$ & $\mathrm{I} .02$ & 3.60 \\
\hline 165 & $8,8,8,8,7 \cdot 5,8,7 \cdot 5,8$ & $7 . \ddot{8}$ & 2.22 & 0.89 & $3.5^{8}$ \\
\hline I95 & $6.5,7,7,6 \cdot 5,6 \cdot 7,6$ & $6 \cdot 6$ & 2.29 & 0.82 & 3.59 \\
\hline 224 & $6,6,6,6,6$ & $6 \cdot 0$ & $2 \cdot 35$ & 0.78 & 3.60 \\
\hline 254 & $4 \cdot 5,5,5,5,4.5,5,5$ & $4 \cdot 8$ & $2 \cdot 40$ & 0.68 & $3 \cdot 5^{8}$ \\
\hline 278 & $4.5,4,4,4.5,4.5,4,4,4.5$ & $4 \cdot 25$ & $2 \cdot 44$ & 0.63 & $3 \cdot 5^{8}$ \\
\hline
\end{tabular}

\section{Action of a mixture of Poisons.}

The following concentrations of poisons were each found just to cause cessation of movement in a culture of Chlamydomonas multifilis in ten minutes :-

$$
\begin{array}{lr}
\text { Hydrochloric acid } & 0.009 \text { per cent. } \\
\text { Pyrocatechin } & 0.1 \text { per cent. } \\
\text { Resorcin } & 0.18 \text { per cent. }
\end{array}
$$

A mixture of 0.009 per cent. $\mathrm{HCl}$ and 0.18 per cent. Resorcin caused cessation of movement before ten minutes, and so did a mixture of 0.009 per cent. $\mathrm{HCl}$ and 0.10 per cent. Pyrocatechin, also a mixture of 0.18 per cent. Resorcin and O.IO per cent. Pyrocatechin. Hence no one of these poisons retards the action of another to any considerable extent.

Further experiments showed the striking fact that a mixture of the poisons, each slightly weaker, viz. :-

0.007 per cent. $\mathrm{HCl}$

0.08 per cent. Pyrocatechin

and O.I4 per cent. Resorcin

does not cause cessation of movement in ten minutes, although each of the three poisons exceeds in strength three-quarters of the concentration which, by itself, will cause movement to cease.

Here it is evident that the action of each poison is specific, and, from the great difference in toxic activity of isomeric modifications of the same compound, the specific action is seen to vary greatly for slight changes in chemical constitution. A mixture of strong acids behaves as if its toxic

\footnotetext{
1 Watson: Journal of Hygiene, Oct. I908.
} 
activity was proportional to the number of free hydrogen ions present, unless, of course, any one of the acids has a further specific toxic action dependent upon the negative ion. (Hunkel and True.)

It seems probable, in the above instance, that the velocity of the reaction due to the mixture of poisons is equal to the sum of the velocities of each specific reaction. When a number of chemical reactions are simultaneously taking place in any system, each proceeds independently of the others, and the total change is the sum of all the independent reactions.

Owing to the difficulty in procuring suitable cultures of Chlamydomonas I have been unable to make conclusive experiments with other mixtures of poisons, but hope to extend the above results next summer. In the meanwhile these results can only be regarded as preliminary.

Finally I have to express my thanks to Miss Chick for several valuable suggestions, and to Dr. F. F. Blackman for his kind help throughout. 


\section{$2 \mathrm{BHL}$ Biodiversity Heritage Library}

Harvey, H. W. 1909. "The action of poisons upon Chlamydomonas and other vegetable cells." Annals of botany 23, 181-187. https://doi.org/10.1093/oxfordjournals.aob.a089210.

View This Item Online: https://www.biodiversitylibrary.org/item/236540

DOI: https://doi.org/10.1093/oxfordjournals.aob.a089210

Permalink: https://www.biodiversitylibrary.org/partpdf/318946

\section{Holding Institution}

Smithsonian Libraries

\section{Sponsored by}

Biodiversity Heritage Library

\section{Copyright \& Reuse}

Copyright Status: Not in copyright. The BHL knows of no copyright restrictions on this item.

This document was created from content at the Biodiversity Heritage Library, the world's largest open access digital library for biodiversity literature and archives. Visit BHL at https://www.biodiversitylibrary.org. 